\title{
ЩОДО ПОСТАНОВЛЕННЯ СУДДЕЮ ЗАВІДОМО НЕПРАВОСУДНОГО ВИРОКУ, РІШЕННЯ, УХВАЛИ АБО ПОСТАНОВИ: ВИКЛИКИ ДЕКРИМІНАЛІЗАЦЇ̈
}

\section{Щербак I. А., Патюк С. O.}

\section{ВСТУП}

Будь-які неправосудні рішення судді є надзвичайно небезпечними для суспільства та держави, оскільки, завдаючи шкоду безпосередньо особам, які беруть участь у вирішенні спорів судом, такі рішення одночасно підривають авторитет судової влади, створюють недовіру до неї у суспільстві, девальвацію в суспільній свідомості права, законності та справедливості, дискредитують Україну як державу. Тому протидія кримінальним правопорушенням, що вчиняються суддею в сфері правосуддя, є одним із головних завдань кримінально-правової політики держави. Саме на реалізацію цього завдання й передбачена кримінальна відповідальність судді за постановлення ним неправосудного рішення (ст. 375 КК України) ${ }^{1}$.

Україна перебуває у перехідному періоді євроінтеграції, що зумовлює спроби змінити законодавчі акти, зокрема у кримінально-правовій сфері, та привести їх у відповідність до європейських стандартів.

Відповідальність за неправосудні дії судді $є$ історично обгрунтованим видом юридичної відповідальності суддів. Подібні правові норми притаманні кримінальному законодавству Естонії, Норвегії, Німеччини, Іспанії, Латвії та інших держав.

Протягом тривалого часу різні аспекти кримінальної відповідальності судді за постановлення завідомо неправосудного судового вироку, рішення, ухвали або постанови досліджувалися у працях П.П. Андрушка, Л.С. Виноградової, М.В. Галабали, Ю.М. Грошевого, О.О. Дудорова, В.М. Сднака, О.В. Капліної, Н.Д. Квасневської, О.В. Кобзевої, А.В. Маляренка, В.О. Навроцького, О.М. Овчаренко, Л.М. Палюха, М.А. Погорецького, М.С. Пономарьова, І.А. Тітка, В.І. Тютюгіна, М.І. Хавронюка, С.В. Хилюк та інших. Вклад кожного дослідника $\epsilon$ корисним для розуміння змісту і правозастосування чинної редакції ст. 375 КК України.

Незважаючи на проведення численних судових реформ, слід зазначити, що рівень недовіри суспільства до судової влади 3 кожним роком збільшується, кількість заяв проти України до Європейського суду з прав

\footnotetext{
${ }^{1}$ Погорецький М.А. Притягнення суддів до кримінальної відповідальності за ст. 375 КК України: проблемні питання матеріального та процесуального права. Вісник кримінального судочинства. 2015. № 2. С. 223.
} 
людини (далі - ССПЛ) зростає, при цьому останній неодноразово вказував у своїх рішеннях на недосконалість судового захисту в Україні.

Вища рада правосуддя в своїх щорічних звітах звертає увагу на поширення випадків ініціювання відкриття кримінальних проваджень за ст. 375 КК України, що вважає засобом тиску на суддів 3 боку правоохоронних органів та осіб, незадоволених судовим рішенням ${ }^{2}$.

Згідно 3 оприлюдненими Генеральною прокуратурою відомостями за період з січня по грудень 2019 року в СРДР було зареєстровано 408 кримінальних проваджень за ст. 375 КК, лише в трьох з яких було повідомлено особу про підозру та тільки 2 надійшло до суду 3 обвинувальним актом ${ }^{3}$.

Слід звернути увагу, що протягом 2019 року було зареєстровано декілька законопроєктів щодо відповідальності суддів за ст. 375 КК України, які передбачали як посилення такої відповідальності, так і його повну декриміналізацію. Так, законопроєкт № 2113 «Про внесення змін до деяких законодавчих актів України щодо оптимізації кримінальної відповідальності суддів за постановлення завідомо неправосудного судового рішення» ${ }^{4}$, крім посилення такої відповідальності, передбачав розширення кваліфікуючих ознак цього злочину та виділення окремого суб'єкта - судді Конституційного суду України. А законопроєктом № 2113-1 «Про внесення змін до статті 375 Кримінального кодексу України щодо приведення у відповідність 3 рекомендацією експертів Групи держав проти корупції Ради Європи» ${ }^{5}$ пропоновано декриміналізувати зазначену статтю, посилаючись на стійку тенденцію зловживання правоохоронними органами інститутом кримінальної відповідальності судді за неправосуддя, яка застосовується 3 метою неправомірного тиску на суддів.

Проте Група держав проти корупції Ради Свропи (GRECO) у п. 114 Звіту 2017 р. звертає увагу на стандарти Ради Європи, які чітко зазначають, що

\footnotetext{
2 Про стан забезпечення незалежності суддів в Україні: щорічна доповідь за 2017 рік. Вища рада правосуддя. Київ. 2018. С. 161. / Офіційний вебпортал Вищої ради правосуддя. URL: http://www.vru.gov.ua/ content/file/Щорічна_доповідь_за_2017_piк_pdf; Про стан забезпечення незалежності суддів в Україні: щорічна доповідь за 2019 рік. Вища рада правосуддя. Київ. 2020. С. 5-8. / Офіційний вебпортал Вищої ради правосуддя. URL: https://hcj.gov.ua/sites/default/files/field/file/shchorichna_dopovid_za_2019_rik.pdf (дата звернення: 20.04.2020).

${ }^{3}$ Єдиний звіт про кримінальні правопорушення по державі за грудень 2019 року. / Офіційний вебпортал Генеральної прокуратури України. URL: https://old.gp.gov.ua/ua/stst2011.html?dir_id=113897 \&libid $=100820 \& \mathrm{c}=$ edit\&_c=fo (дата звернення: 19.05.2020).

4 Про внесення змін до деяких законодавчих актів України щодо оптимізації кримінальної відповідальності суддів за постановлення завідомо неправосудного судового рішення : проєкт Закону № 2113 від 10.09.2019 року. / Офіційний вебпортал Верховної Ради України. URL: http://w1.c1.rada.gov.ua/ pls/zweb2/webproc4_1?id=\&pf3511=66782 (дата звернення: 20.05.2020).

${ }^{5}$ Про внесення змін до статті 375 Кримінального кодексу України щодо приведення у відповідність 3 рекомендацією експертів Групи держав проти корупції Ради Європи : проєкт Закону № 2113-1 від 26.09.2019 року. / Офіційний вебпортал Верховної Ради України. URL: http://w1.c1.rada.gov.ua/pls/ zweb2/webproc4_1?id=\&pf3511=66952 (дата звернення: 20.05.2020).
} 
«тлумачення закону, оцінювання фактів або доказів, які здійснюють судді для вирішення справи, не повинні бути приводом для кримінальної відповідальності, крім випадків злочинного наміру» ${ }^{6}$. Отже, виходячи 3 цього, наявність ст. 375 у КК України відповідає стандартам Ради Свропи.

Наведене свідчить про актуальність і своєчасність вибраної тематики наукового дослідження, підтверджує необхідність узагальнення й уточнення критеріїв «неправосудності» судового рішення, а також формування пропозицій щодо подолання детермінантів, якими обгрунтовується необхідність декриміналізації ст. 375 КК України.

\section{1. Щодо основних критеріїв (ознак) неправосудності судового рішення}

Крім Кримінального кодексу України (ст.ст. 375, 376), термін «неправосудне» застосовується в Конституції України (ст. 62), міжнародних актах, рішеннях Конституційного Суду України, указах Президента України, постанові Пленуму Верховного Суду. У зв'язку з тим, що жоден із НПА натепер не розкриває зміст зазначеного поняття, науковці i практики періодично ведуть дискусії навколо правозастосування ст. 375 КК України (напр., щодо тлумачення терміна «неправосудне судове рішення», перейменування статті, моменту виникнення неправосудності, розмежування кримінальної і дисциплінарної відповідальності судді за неправосуддя та ін.).

Окремі дослідники вважають, що відсутність тлумачення юридичного змісту терміна «неправосудність» «призводить до проблеми індивідуального сприйняття цього терміна в судовій практиці» ${ }^{7}$. А інші не вбачають проблеми у використанні цього терміна (О.О. Дудоров, Л.М. Палюх) ${ }^{8}$, справедливо зауважують, що термін «неправосудний» більш чітко вказує на коло суспільних відносин, охоронюваних за допомогою ст. 375 КК України: незаконні дії може вчинити будь-яка особа, а неправосудні - лише суддя (B.М. Сднак) ${ }^{9}$.

Більшість суддів і науковців вважають, що результати кримінальноправового реагування на поведінку суддів $\epsilon$ правозастосовною проблемою, яка безпосередньо не стосується якості кримінального закону - ст. 375 КК

\footnotetext{
6 Звіт за результатами оцінки України. Запобігання корупції серед народних депутатів, суддів та прокурорів. Четвертий раунд оцінювання Групи держав проти корупції Ради Свропи (GRECO) від 23.06.2017. Страсбург. 73 с. URL: http://www.eurointegration.com.ua/news/2017/08/8/7069545/ (дата звернення: 10.05.2020).

7 Тютюгін В.I., Капліна О.В., Тітко I.А. Постановлення суддею завідомо неправосудного вироку, рішення, ухвали або постанови: окремі аспекти застосування ст. 375 Кримінального кодексу України. Вісник Верховного Суду Украӥни. 2012. № 2. С. 42.

${ }^{8}$ Дудоров О.О., Палюх Л.М. Проблеми кримінально-правової характеристики злочину, передбаченого статтею 375 КК України. Вісник Асоціації̈ кримінального права України, 2016. № 1(6). C. 280. URL: http://nauka.nlu.edu.ua/wp-content/uploads/2016/07/20_Dudorov.pdf. (дата звернення: 10.05.2020).

9 Єднак В.М. Кримінальна відповідальність за постановлення суддею (суддями) завідомо неправосудного вироку, рішення, ухвали або постанови з корисливих мотивів : дис. ... канд. юрид. наук : 12.00.08 «Кримінальне право та кримінологія; кримінально-виконавче право». НАН України, Ін-т держави і права ім. В.М. Корецького. Київ, 2015. С. 89 (200 с.)
} 
України. Вони вважають великою проблемою у разі ії правозастосування доказування того, що рішення $є$ не просто незаконним, а неправосудним, тобто таким, яке неможливо вважати судовим рішенням. При цьому воно прийнято $з$ грубими порушеннями не тому, що $\epsilon$ спір про практику застосування судами норм законодавства, не тому, що суддя неправильно розуміє норму, він завідомо знав, що приймає рішення, яке протирічить нормам, духу права, і бажав його постановити ${ }^{10}$.

У рамках роботи над проєктом Постанови Пленуму ВССУ «Про судову практику розгляду кримінальних проваджень, пов'язаних з винесенням суддею (суддями) завідомо неправосудного вироку, рішення, ухвали або постанови (стаття 375 УК України)» в 2016 році було проведено два засідання Пленуму, проєкт Постанови був прийнятий у першому читанні, відбулися обговорення в робочих групах, але через відсутність єдності в ключових питаннях як з боку суддів, так і з боку науковців постанову в цілому не було прийнято ${ }^{11}$.

У 2017 році Верховний Суд України (ВСУ) звертався до Конституційного Суду України стосовно офіційного тлумачення словосполучення «як неправосудного», що міститься у ч. 4 ст. 62 Конституції України. В конституційному поданні ВСУ наголошував, що «таке офіційне тлумачення дасть змогу кожному судді i суду під час здійснення правосуддя визначитися, яке саме рішення $є$ неправосудним, оскільки нині у практичній реалізації відповідних положень законодавства формується неоднакове розуміння поняття «неправосудний» органами досудового розслідування та судами».

Конституційний Суд України в Ухвалі від 29.05.2017 р. № 9-у/2017 про відмову у відкритті провадження зазначив, що Верховний Суд України намагався з'ясувати порядок та особливості притягнення до кримінальної відповідальності на підставі ст. 375 КК осіб, винних у постановленні завідомо неправосудного вироку, рішення, ухвали або постанови, шляхом тлумачення зазначеної норми кримінального закону, а також зміст понять «незаконний», «необгрунтований», що містяться у законах України, на які він посилався, що відповідно до ст. 150 Конституції це питання не належить до повноважень Конституційного Суду України ${ }^{12}$.

\footnotetext{
${ }^{10}$ Что думают судьи о статье 375 КК України «Постановление судьёй (судьями) заведомо неправосудного приговора, решения, определения или постановления». Протокол: юридичний інтернет-ресурс. 06.04.2016 p.

${ }_{11}$ Верховний Суд попросив роз'яснити «неправосудність» Судова влада України: вебсайт. URL: https://ko.mk.court.gov.ua/sud1415/pres-centr/news/325535/ (дата звернення: 20.05.2020).

12 Про відмову у відкритті конституційного провадження у справі за конституційним поданням Верховного Суду України щодо офіційного тлумачення словосполучення «як неправосудного», що міститься у частині четвертій статті 62 Конституції України : Ухвала Конституційного Суду України від 29.05.2017 p. № 9-y/2017. / Офіційний вебпортал Верховної Ради України. URL: https://zakon.rada.gov.ua/ laws/show/v009u710-17 (дата звернення: 20.04.2020).
} 
Поширеним в юридичній літературі є твердження, що неправосудність судового рішення варто розглядати крізь призму його незаконності та необгрунтованості, оскільки вирок може бути або правосудним, тобто законним та обгрунтованим, або неправосудним, тобто незаконним та необгрунтованим ${ }^{13}$. 3 цього приводу В.М. Єднак вважає, що законне рішення не завжди може бути вмотивованим i, навпаки, незаконне рішення може бути належно вмотивованим.

М.А. Погорецький, крім невідповідності судового рішення стандартам законності, обгрунтованості, вмотивованості, ще вказує на невідповідність такого рішення стандартам справедливості, розумності та своєчасності. Також $є$ думки, що для визнання судового рішення неправосудним необхідно, щоб його неправосудність була підтверджена вищестоящою судовою інстанцією ${ }^{14}$; судові рішення, які підлягають оскарженню відповідно до КПК, мають бути скасовані, тобто визнані незаконними в порядку, передбаченому КПК ${ }^{15}$. Водночас окремі дослідники зазначають, що неправосудним може виявитися рішення вищої судової інстанції16. Інші зауважують, що визнання обов'язковою умовою кримінальної відповідальності судді за постановлення завідомо неправосудного рішення факту скасування цього рішення породжує питання, як бути із судовими рішеннями, які відповідно до процесуального законодавства (зокрема, КПК України) не підлягають оскарженню ${ }^{17}$.

Істотні аргументи на користь положення про те, що відповідальність за ст. 375 КК України має наставати незалежно від того, чи скасоване (змінене) неправосудне судове рішення, виклав В.О. Навроцький ${ }^{18}$.

На думку Л.С. Виноградової, під «неправосудним» вироком варто розуміти незаконний судовий акт, що ухвалений умисно або в результаті недбалості, і відзначає, що в результаті цього завдано істотної шкоди правам та інтересам громадян чи інтересам держави ${ }^{19}$.

\footnotetext{
${ }^{13}$ Грошевий Ю.М. Правові властивості вироку - акта правосуддя : навчальний посібник. Харків, 1994. С. 21

${ }^{14}$ Дудоров О.О., Хавронюк М.І. Кримінальне право : навчальний посібник / за ред. М.І. Хавронюка. Київ : Ваіте, 2014. С. 801.

${ }^{15}$ Гродзинська К. Окремі питання притягнення суддів до кримінальної відповідальності за ухвалення завідомо неправосудного рішення. Віче. 2015. № 10. С. 2-6.

${ }^{16}$ Дудоров О.О., Палюх Л.М. Проблеми кримінально-правової характеристики злочину, передбаченого статтею 375 КК України. Вісник Асоиіаџї̈ кримінального права України, 2016. № 1(6). С. 280. URL: http://nauka.nlu.edu.ua/wp-content/uploads/2016/07/20_Dudorov.pdf. (дата звернення: 02.05.2020).

17 Андрушко П. Науковий висновок (доповнений) по запиту адвоката Павленка М.В. щодо правильності і обгрунтованості кримінально-правової кваліфікації органом досудового розслідування дій Волкової С.Я. за ст. 375 КК

${ }_{18}^{18}$ Навроцький В.О. 3 професорської шухляди. Івано-Франківськ : Фоліант, 2016. С. 399-402.

${ }^{19}$ Виноградова Л.С. Юридична відповідальність суддів загальних судів України : дис... канд. юрид. наук : 12.00 .10 «Судоустрій; прокуратура та адвокатура». Одес. нац. юрид. акад. Міністерства освіти і науки України. Одеса, 2004. С. 9.
} 
О.О. Дудоров та Л.М. Палюх указують на важливість кваліфікації цього злочину за об'єктивними ознаками, що відрізняють його від незаконних та (або) необгрунтованих судових рішень, постановлення яких злочином не визнається; зазначають, що постановлення завідомо неправосудного судового рішення повинне бути суспільно небезпечним діянням, тобто заподіювати або створювати можливість заподіяння істотної шкоди охоронюваним законом суспільним відносинам ${ }^{20}$.

П.П. Андрушко визначив, що в кримінально-правовому значенні (аспекті) неправосудність судового рішення - це кримінально-правова оцінка (кваліфікація) судового рішення стороною обвинувачення й судом, яка зумовлюється (визначається) психічним ставленням судді, котрий його ухвалив, до змісту ухваленого ним рішення та дотримання вимог процесуального закону щодо здійснення відповідного провадження: суддя має усвідомлювати, що ухвалене ним рішення є незаконним, необгрунтованим або невмотивованим, незалежно від того, чим він при цьому керувався і якою була мета ухвалення неправосудного рішення» ${ }^{21}$.

У контексті наукового тлумачення конструкції, передбаченої ст. 375 КК України, О.М. Овчаренко визначає критерії, за якими судове рішення може визнаватися неправосудним: 1) явні, очевидні порушення суддею матеріального або процесуального закону, які свідчать про несумлінність, нечесність, упередженість судді під час здійснення ним правосуддя, як-то: вчинення дій, які прямо заборонені процесуальним законом, або ігнорування норми матеріального закону; 2) встановлення факту грубого порушення суддею матеріального або процесуального закону вищим судом під час оскарження відповідного рішення, що потягло його зміну або скасування; 3) наявність прямого умислу судді на постановлення завідомо неправосудного вироку, рішення, ухвали або постанови, який підтверджений фактичними обставинами справи; 4) вчинення злочину з корисливих мотивів або $з$ метою отримання неправомірної вигоди; 5) негативні наслідки, що перебувають у прямому причинному зв'язку з діями судді: якщо внаслідок рішення настали суттєві порушення прав і законних інтересів особи, декількох осіб, групи осіб або держави; якщо ці наслідки неможливо усунути; якщо неправомірне діяння судді мало значний суспільний резонанс або підриває суспільну довіру до суду ${ }^{22}$. «Упередженість» у цьому контексті

\footnotetext{
${ }^{20}$ Дудоров О.О., Хавронюк М.І. Кримінальне право : навчальний посібник / за ред. М.І. Хавронюка. Київ : Ваіте, 2014. С. 794-796.

${ }^{21}$ Андрушко П.П. Деякі проблемні питання кримінально-правової кваліфікації постановлення суддею (суддями) завідомо неправосудного рішення в кримінальному провадженні (ст. 375 КК). Вісник Верховного Суду України. 2014. № 8. С. 38.

${ }_{22}$ Овчаренко О.М. Юридична відповідальність суддів: питання теорії і практики : автореф. дис. ... д-ра юрид. наук : 12.00.10 «Судоустрій; прокуратура та адвокатура». Нац. ун-т «Одес. юрид. акад.». Одеса, 2018. С. 17.
} 
визначається науковцем як вчинення дій, які прямо заборонені процесуальним законом, або ігнорування норми матеріального закону.

Н.Д. Квасневською «неправосудність» судового рішення розглядається як виражена у неправильному застосуванні некомпетентним або (i) упередженим суддею норм матеріального і (або) процесуального права, невідповідність судового акту (вироку, рішення, ухвали, постанови) фактичним обставинам юридичного конфлікту та наявним у суспільстві уявленням про справедливість і законність. Упередженість, на думку вченої, свідчить про зацікавленість у неправильному вирішенні справи ${ }^{23}$.

Академічний тлумачний словник української мови визначає «упереджений» як: 1) який склався щодо кого-, чого-небудь наперед, до ознайомлення 3 ним; необ'єктивний; 2) негативний, несправедливий, який складається щодо кого-, чого-небудь наперед ${ }^{24}$.

Виходячи 3 цього, вважаємо, що термін «упереджений» не є суттєвим критерієм для праворозуміння категорії «неправосудність» i потребує подальшого уточнення стосовно ст. 375 КК України.

Крім того, важливим аспектом дослідження у сенсі дотримання принципу верховенства права під час постановлення судового рішення слід зазначити розмежування понять «якість» судового рішення та його завідомо усвідомлена неправосудність.

Аналізуючи процедурне законодавство, слід відзначити, що загалом його вимоги до «якості» судового рішення полягають у такому: судове рішення повинно грунтуватися на засадах верховенства права, бути законним i обгрунтованим. Законним $є$ рішення, ухвалене судом відповідно до норм матеріального права із дотриманням норм процесуального права. Обгрунтованим є рішення, ухвалене на підставі повно і всебічно з'ясованих обставин, на які сторони посилаються, як на підставу своїх вимог і заперечень, підтверджених тими доказами, які були досліджені в судовому засіданні з дотриманням принципу безпосередності.

Ухвалення судового рішення, яке не відповідає умовам вмотивованості та обгрунтованості, тягне за собою низку негативних наслідків як для учасників справи, так і для судді, який прийняв таке рішення. Зокрема, для учасників справи постановлення немотивованого (не досить мотивованого) рішення означає, що доводи та аргументи, а також надані для доведення певних обставин справи докази не були почуті та належним чином оцінені судом, що своєю чергою може призвести до прийняття неправосудного

\footnotetext{
23 Квасневська Н.Д. Кримінальна відповідальність за неправосуддя в Україні : монографія. Київ : Юрінком Інтер. 2010. С. 55, 57, 163.

24 Академічний тлумачний словник української мови. URL: http://sum.in.ua/s/zavidomo (дата звернення: 15.04.2020).
} 
рішення, а у перспективі - до свавілля судової влади. Для судді притягнення до відповідальності, встановленої законом.

Аналіз судової практики показує, що в судових рішеннях містяться основні критерії «неправосудності» судового рішення, які співпадають 3 позиціями науковців. Наприклад, Верховний Суд у постанові від 20.05.2019 року у справі 399/383/15-к зазначив, що на законодавчому рівні не визначено поняття «неправосудне судове рішення», не розтлумачено його і Конституційним Судом України, відсутні підстави ототожнювати його з такими поняттями, як «незаконне» та «необгрунтоване», а також немає підстав стверджувати, що неправосудне судове рішення - це у будьякому разі таке рішення, яке було скасоване вищою судовою інстанцією. Крім цього, наголошено, що поняття «неправосудне судове рішення» у поєднанні з вказівкою на «завідомість» його постановлення підкреслює цілеспрямований характер злочинних дій судді, його свідоме прагнення та бажання всупереч матеріальному чи процесуальному закону і (або) фактичним обставинам, встановленим у справі, постановити судове рішення, яке за своєю суттю не може бути i не є актом правосуддя ${ }^{25}$. У рішенні Верховного Суду України від 20.11.2014 р. у справі № 5-24кс14 зазначено, що постановлення завідомо неправосудного судового акта $\epsilon$ спеціальним видом службового зловживання в сфері здійснення правосуддя, суб'єкт якого (суддя) умисно за будь-якими мотивами свідомо і цілеспрямовано використовує свій службовий стан усупереч інтересам правосуддя... Суб'єктивна сторона злочину характеризується прямим умислом: суддя достовірно знає, переконаний у тому, що чинить усупереч вимогам закону і справедливості... Злочин визнається закінченим 3 моменту проголошення винесеного судового акта незалежно від часу його набуття законної сили і наслідків, їм викликаних ${ }^{26}$. У рішеннях акцентується увага на обов'язкову ознаку суб'єктивної сторони, яка встановлена законом у диспозиції ч. 1 ст. 375 КК, - «завідомість» постановлення неправосудного судового рішення.

У зв'язку з наведеним вище слушним є висновок В.М. Будріна, який зазначає: «Скасованих рішень немало, проте незаконне i завідомо неправосудне рішення - це зовсім різні поняття. Тому найбільшою проблемою, пов'язаною із застосуванням ст. 375 КК України, «наріжним каменем» $€$ процесуальне доказування того, що судове рішення $\epsilon$ не просто

\footnotetext{
25 Постанова Верховного Суду від 20.05.2019 року у справі 399/383/15-к. Сдиний державний реєстр судових рішень. URL: http://reyestr.court.gov.ua/Review/82541702 (дата звернення: 23.04.2020).

${ }^{26}$ Рішення Верховного Суду України у справі № 5-24кс14 від 20.11.2014 р. Сдиний державний реєстр судових рішень. URL: http://www.viaduk.net/clients/vsu/vsu.nsf/(documents)/196768197BCBF85DC 2257DCC0032E65E. (дата звернення: 23.01.2020)
} 
незаконним, а завідомо неправосудним (наявність прямого умислу), тобто таким, що фактично не може вважатися судовим рішенням» ${ }^{27}$.

Отже, на підставі узагальнення та аналізу доктринальних та прикладних положень щодо сутності категорії завідомо неправосудного судового рішення, що тягне за собою кримінальну відповідальність за ст. 375 КК України, до основних (невиключних) критеріїв «неправосудності» можна віднести: 1) завідому умисну невідповідність судового рішення вимогам законності та обгрунтованості; 2) свідоме умисне порушення норм процесуального права у разі прийняття судового рішення; 3) свідоме умисне ігнорування суддею фактичних обставин справи у разі прийняття рішення; 4) наявність корисних спонукань або інших особистих інтересів під час постановлення судового рішення; 5) проголошення (ухвалення) неправосудного судового рішення.

При цьому вважаємо, що наявність істотної шкоди як остаточного критерію для віднесення дій судді до кримінально караних не має значення, з огляду на те, що сам по собі факт проголошення завідомо неправосудного судового рішення підриває авторитет судової влади та довіру до неї, що вже само по собі є завданням шкоди інтересам держави.

\section{2. Кримінальна відповідальність за завідомо неправосудне судове рішення - декриміналізація чи модернізована легалізація}

18 травня 2020 року у Верховній Раді України було зареєстровано проєкт Закону «Про внесення змін до Кримінального кодексу України щодо відповідальності за постановлення суддею (суддями) упередженого судового рішення» (далі - проєкт Закону). У законопроєкті пропонується ст. 375 КК України викласти в редакції, відповідно до якої кримінально караним буде вважатися постановлення суддею упередженого судового рішення, в якому завідомо неправильно застосовано норму матеріального права, або яке постановлено з грубим порушенням норм процесуального права, або в якому завідомо є невідповідність висновків суду фактичним обставинам справи. Крім того, як додаткові кваліфікуючі ознаки, які впливають на тяжкість покарання, зазначені тяжкі наслідки, корисливі мотиви або інші особисті інтереси, чи постановлення такого судового рішення 3 метою перешкоджання законній професійній діяльності журналіста ${ }^{28}$.

\footnotetext{
27 Бурдін В.М. Окремі питання кримінальної відповідальності за постановлення суддею (суддями) завідомо неправосудного вироку, рішення, ухвали або постанови. Актуальні питання кримінального права, кримінального процесу та криміналістики : матеріали Міжнар. наук.-практ. конф. (Львів, 29 січ. 2016 р.). Львів : Вид-во Львів. політехніки, 2016. С. 11.

28 Проєкт Закону про внесення змін до Кримінального кодексу України щодо відповідальності за постановлення суддею (суддями) упередженого судового рішення. / Офіційний вебпортал Верховної Ради України. URL: http://w1.c1.rada.gov.ua/pls/zweb2/webproc4_1?pf3511=68868 (дата звернення: 22.05.2020).
} 
Автори законопроєкту вважають, що 3 метою забезпечення гарантованого Конституцією України принципу незалежності судової влади, запобіганню тиску на судову владу з боку правоохоронних органів та $з$ огляду на позицію Верховного Суду щодо відсутності визначення на законодавчому рівні поняття «неправосудне судове рішення» альтернативою запропонованій раніш декриміналізації може стати нова редакція ст. 375 КК України, в якій із дотриманням принципу правової визначеності ознаки кримінального правопорушення будуть викладені із зазначенням конкретних критеріїв, таких як: упередженість, завідомість, невідповідність матеріальному праву, грубе порушення процесуальних норм, суперечність висновків суду фактичним обставинам.

Питання доведення упередженості суддів неодноразово було предметом дослідження ЄСПЛ, наприклад, у справі «Іліє проти Румунії» (заява № 26220/10), «Мироненко і Мартенко проти України» та ін. За наслідками розгляду зазначених справ ССПЛ зазначає, що доводи щодо упередженості повинні бути основані на фактичних обставинах, тобто припущення до уваги не беруться. Особиста безсторонність суду презумується, поки не надано доказів протилежного. Згідно з усталеною практикою Суду, наявність безсторонності має визначатися для цілей пункту 1 статті 6 Конвенції за допомогою суб'єктивного та об'єктивного критеріїв. За суб'єктивним критерієм оцінюється особисте переконання та поведінка конкретного судді, тобто чи виявляв суддя упередженість або безсторонність у такій справі. Відповідно до об'єктивного критерію визначається серед інших аспектів, чи забезпечував суд як такий та його склад відсутність будь-яких сумнівів у його безсторонності. Вирішальне значення при цьому матиме можливість вважати такі сумніви об'єктивно обгрунтованими (Ferrantelli and Santangelo v. Italy), рішення від 7 серпня 1996 року, Reports 1996-III, с. 951-952, п. 58 $)^{29}$.

Як встановлюють Бангалорські принципи поведінки суддів, схвалені резолюцією 2006/23 Економічної і соціальної ради ООН від 27 липня 2006 року, об'єктивність судді $є$ необхідною умовою для належного виконання ним своїх обов'язків. Вона проявляється не тільки у змісті винесеного рішення, а й у всіх процесуальних діях, що супроводжують його прийняття ${ }^{30}$.

Таким чином, з урахуванням того, що упередженість судді під час прийняття судового рішення $є$ обставиною, яка поруч з іншими ознаками суб'єктивної сторони кримінального правопорушення, передбаченого

\footnotetext{
29 Проєкт Закону про внесення змін до Кримінального кодексу України щодо відповідальності за постановлення суддею (суддями) упередженого судового рішення. / Офіційний вебпортал Верховної Ради України. URL: http://w1.c1.rada.gov.ua/pls/zweb2/webproc4_1?pf3511=68868 (дата звернення: 22.05.2020)

${ }^{30}$ Там само.
} 
ст. 375 КК України у запропонованій у проєкті Закону редакції, підлягає доказуванню, а законодавство не встановлює суб'єктивних та об'єктивних критеріїв упередженості, як і не встановлює критеріїв неправосудності, про що неодноразово в своїх рішеннях зазначав Верховний Суд, модернізація ст. 375 КК України у такий спосіб не вирішує проблеми їі правозастосування (не впливає на правозастосування).

При цьому встановлення кримінальної відповідальності за умисне постановлення суддею неправосудного рішення не суперечить сучасним європейським стандартам незалежності суддів.

Той факт, що наявну кримінально-правову заборону іноді намагаються використати для неналежного впливу (тиску) на суд не $\epsilon$ вагомим аргументом для вилучення статті з тексту Кримінального кодексу України.

Безумовно, у реалізації завдань забезпечення верховенства права та пріоритетності прав людини у разі їх захисту від суддівського неправосуддя слід чітко дотримуватися межі, яка гарантує суддям під час прийняття рішення конституційні презумпції самостійності та незалежності судової влади, що можливо зробити шляхом застосування законодавчо встановлених механізмів реагування на випадки протиправного втручання в діяльність судді під час здійснення правосуддя.

Саме про необхідність вирішення актуальних питань щодо правозастосування ст. 375 КК України свідчить підготовлений у рамках Програми реформування сектору юстиції «Нове правосуддя» USAID аналітичний звіт, у висновках якого з метою усунення перелічених у звіті проблемних аспектів було рекомендовано внесення відповідних змін до КПК України, які б сприяли попередженню звернення до органів розслідування щоразу у випадку незгоди з ухваленим судовим рішенням, а також передбачали спеціальну процедуру по зазначеній категорії кримінальних проваджень, яка би виключала «автодинамічний» порядок початку досудового розслідування.

\section{ВИСНОВКИ}

У результаті аналізу доктринальних позицій, судової практики, поглядів на зазначену проблематику безпосередньо суддів зроблені такі висновки.

1. Необхідність існування статті 375 , якою передбачена відповідальність судді за постановлення суддею (суддями) завідомо неправосудного вироку, рішення, ухвали або постанови, в Кримінальному кодексі України не викликає сумнівів. Виключення цієї статті призведе до декриміналізації кримінально карного діяння як одного $з$ елементів системи стримувань та противаг у механізмі державної влади, що забезпечує рівноправність гілок державної влади у разі ії поділі на судову, виконавчу та законодавчу та $\epsilon$ 
інструментом, що запобігає свавіллю суду, обмежуючи «власне переконання» конкретними законодавчо встановленими критеріями щодо неупередженості суду, якості судового рішення та розумності строків здійснення правосуддя в конкретній справі із забезпечення конвенційного права на доступ до суду.

2. Особливість застосування статті 375 КК України полягає у доказуванні «завідомо неправосудного» судового рішення. «Завідомість неправосудного» судового рішення залежить від встановлення органом досудового розслідування та доведеності перед судом 3 боку обвинувачення умислу судді у разі постановлення такого рішення. При цьому наявність судового рішення в порядку процесуального оскарження про скасування або зміну судового рішення не $\epsilon$ обов'язковим критерієм, що вказує на неправосудність 3 огляду на те, що процесуально існують остаточні судові рішення (у тому числі так звані «протокольні» ухвали), оскарження яких $є$ декларативно неможливим.

3. 3 метою уточнення категорії «неправосудне», що застосовується в розрізі кримінально-правової відповідальності судді, пропонуємо законодавче закріплення суттєвих критеріїв «неправосудності» (у тому числі як примітки до ст. 375 КК України), які не є виключними, можуть мати інші споріднені інтерпретації. Але саме закріплення їх як «суттєвих» надають можливість у разі кваліфікації дій судді як неправосудних розмежувати вид юридичної відповідальності спеціального суб'єкта та забезпечити виконання завдань кримінального провадження під час притягнення його до кримінальної відповідальності.

4. Спірні питання правозастосування ст. 375 КК України можуть бути вирішені найвищим судовим органом, який має сформувати відповідну практику та єдність підходу до визначення ознак неправосуддя, або Конституційним судом України, який шляхом реалізації повноважень, передбачених ст. 7 Закону України «Про Конституційний Суд України», має офіційно розтлумачити ст. 62 Конституції України щодо того, коли саме має місце «скасування вироку як неправосудного».

Вважаємо, що сформульовані нами пропозиції суттєво сприятимуть зменшенню дискусій щодо питань «неправосудності» судових рішень та вирішать спірні питання правозастосування ст. 375 КК України 3 дотриманням принципу правової визначеності як елемента верховенства права.

\section{АНОТАЦІЯ}

Наукове дослідження присвячене актуальним теоретико-прикладним аспектам інституту кримінальної відповідальності судді (суддів) за 
постановлення завідомо неправосудного вироку, рішення, ухвали або постанови. Досліджуються перспективи зміни статті 375 Кримінального кодексу України. На підставі аналізу, систематизації та узагальнення наукових розробок, міжнародних правових актів, практики Верховного Суду, прецедентної практики Європейського суду 3 прав людини та сучасного стану кримінального законодавства уточнено коло суттєвих критеріїв категорії «неправосудність» у контексті правозастосування статті 375 Кримінального кодексу України, визначені пропозиції щодо подолання детермінантів, якими обгрунтовується необхідність ії декриміналізації. Визначаються пріоритетні напрями вирішення зазначених проблем, у тому числі пропонується необхідність законодавчого закріплення критеріїв категорії «неправосудності» судового рішення, а також сформульовані інші пропозиції, спрямовані на удосконалення інституту кримінальної відповідальності судді (суддів) за постановлення завідомо неправосудного вироку, рішення, ухвали або постанови.

\section{ЛІТЕРАТУРА}

1. Погорецький М.А. Притягнення суддів до кримінальної відповідальності за ст. 375 КК України: проблемні питання матеріального та процесуального права. Вісник кримінального судочинства. 2015. № 2. C. 223-234.

2. Про стан забезпечення незалежності суддів в Україні: щорічна доповідь за 2017 рік. Вища рада правосуддя. Київ. 2018. С. 161. / Офіційний вебпортал Вищої ради правосуддя. URL: http://www.vru.gov.ua/content/file/Щорічна_доповідь_за_2017_piк_.pdf; Про стан забезпечення незалежності суддів в Україні: щорічна доповідь за 2019 рік. Вища рада правосуддя. Київ. 2020. С. 5-8. / Офіційний вебпортал Вищої ради правосуддя. URL: https://hcj.gov.ua/sites/default/files/field/file/ shchorichna_dopovid_za_2019_rik.pdf (дата звернення: 20.04.2020).

3. Сдиний звіт про кримінальні правопорушення по державі за грудень 2019 року. / Офіційний вебпортал Генеральної прокуратури України. URL: https://old.gp.gov.ua/ua/stst2011.html?dir_id=113897\&libid=100820\&c=edit\&_ $\mathrm{c}=$ fo (дата звернення: 19.05.2020).

4. Про внесення змін до деяких законодавчих актів України щодо оптимізації кримінальної відповідальності суддів за постановлення завідомо неправосудного судового рішення : проєкт Закону № 2113 від 10.09.2019 року. / Офіційний вебпортал Верховної Ради України. URL: http://w1.c1.rada.gov.ua/pls/zweb2/webproc4_1?id=\&pf3511=66782 (дата звернення 20.05.2020). 
5. Про внесення змін до статті 375 Кримінального кодексу України щодо приведення у відповідність з рекомендацією експертів Групи держав проти корупції Ради Європи: проєкт Закону № 2113-1 від 26.09.2019. / Офіційний вебпортал Верховної Ради України. URL: http://w1.c1.rada.gov.ua/pls/zweb2/ webproc4_1?id=\&pf3511=66952 (дата звернення: 20.05.2020).

6. Звіт за результатами оцінки України. Запобігання корупції серед народних депутатів, суддів та прокурорів. Четвертий раунд оцінювання Групи держав проти корупції Ради Європи (GRECO) від 23.06.2017. Страсбург. 73 с. URL: http://www.eurointegration.com.ua/news/2017/08/8/ 7069545/ (дата звернення: 10.05.2020).

7. Тютюгін В.I., Капліна О.В., Тітко І.А. Постановлення суддею завідомо неправосудного вироку, рішення, ухвали або постанови: окремі аспекти застосування ст. 375 Кримінального кодексу України. Вісник Верховного Суду Украӥни. 2012. № 2. С. 42-48.

8. Дудоров О.О., Палюх Л.М. Проблеми кримінально-правової характеристики злочину, передбаченого статтею 375 КК України. Вісник Асойіаџії кримінального права України, 2016. № 1(6). С. 280-328. URL: http://nauka.nlu.edu.ua/wp-content/uploads/2016/07/20_Dudorov.pdf. (дата звернення: 25.02.2020).

9. Сднак В.М. Кримінальна відповідальність за постановлення суддею (суддями) завідомо неправосудного вироку, рішення, ухвали або постанови 3 корисливих мотивів : дис. ... канд. юрид. наук : 12.00 .08 «Кримінальне право та кримінологія; кримінально-виконавче право». НАН України, Ін-т держави і права ім. В.М. Корецького. Київ, 2015. 200 с.

10. Что думают судьи о статье 375 КК України «Постановление судьёй (судьями) заведомо неправосудного приговора, решения, определения или постановления». Протокол: юридичний інтернет-ресурс. 06.04.2016 p. URL: https://protocol.ua/ua/chto_dumayut_sudi_o_state_375_kk_ukraini_ postanovlenie_sudyoy_\%28sudyami\%29_zavedomo_nepravosudnogo_prigovor a_resheniya_opredeleniya_ili_postanovleniya/ (дата звернення: 30.02.2020).

11. Верховний Суд попросив роз'яснити «неправосудність». Судова влада: вебсайт. URL: https://ko.mk.court.gov.ua/sud1415/pres-centr/news/ 325535/ (дата звернення: 20.05.2020).

12. Про відмову у відкритті конституційного провадження у справі за конституційним поданням Верховного Суду України щодо офіційного тлумачення словосполучення «як неправосудного», що міститься у частині четвертій статті 62 Конституції України: Ухвала Конституційного Суду України від 29.05.2017 р. № 9-у/2017. / Офіційний вебсайт Конституційного Суду України. URL: https://zakon.rada.gov.ua/laws/show/v009u71017 (дата звернення: 7.04.2020). 
13. Грошевий Ю.М. Правові властивості вироку - акта правосуддя : навчальний посібник. Харків, 1994. 48 с.

14. Дудоров О.О., Хавронюк М.I. Кримінальне право : навчальний посібник / за ред. М.І. Хавронюка. Київ : Ваіте, 2014. 801 с.

15. Гродзинська К. Окремі питання притягнення суддів до кримінальної відповідальності за ухвалення завідомо неправосудного рішення. Віче. 2015. № 10. С. 2-6.

16. Андрушко П. Науковий висновок (доповнений) по запиту адвоката Павленка М.В. щодо правильності і обгрунтованості кримінально-правової кваліфікації органом досудового розслідування дій Волкової С.Я. за ст. 375 КК України (продовження). Юридичний вісник України (Інформаційноправовий банк). 2015. № 28. 18-24 лип. С. 2-10.

17. Навроцький В.О. 3 професорської шухляди. Івано-Франківськ : Фоліант, 2016. 705 с.

18. Виноградова Л.Є. Юридична відповідальність суддів загальних судів України : дис... канд. юрид. наук : 12.00.10 «Судоустрій; прокуратура та адвокатура». Одес. нац. юрид. акад. Міністерства освіти і науки України. Одеса, 2004. 187 с.

19. Андрушко П.П. Деякі проблемні питання кримінально-правової кваліфікації постановлення суддею (суддями) завідомо неправосудного рішення в кримінальному провадженні (ст. 375 КК). Вісник Верховного Суду Украӥни. 2014. № 8. С. 35-46.

20. Овчаренко О.М. Юридична відповідальність суддів: питання теорії і практики : автореф. дис. ... д-ра юрид. наук : 12.00 .10 «Судоустрій; прокуратура та адвокатура». Нац. ун-т «Одес. юрид. акад.». Одеса, 2018. 42 с.

21. Квасневська Н.Д. Кримінальна відповідальність за неправосуддя в Україні : монографія. Київ : Юрінком Інтер. 2010. 181 с.

22. Академічний тлумачний словник української мови. URL: http://sum.in.ua/s/zavidomo (дата звернення: 15.05.2020).

23. Постанова Верховного Суду від 20.05.2019 року у справі 399/383/15-к. Єдиний державний реєстр судових рішень. URL: http://reyestr.court.gov.ua/Review/82541702 (дата звернення: 3.04.2020).

24. Рішення Верховного Суду України у справі № 5-24кс14 від 20.11.2014 p. Єдиний державний реєстр судових рішень. URL: http://www.viaduk.net/clients/vsu/vsu.nsf/(documents)/196768197BCBF85DC2 257DCC0032E65E. (дата звернення: 23.01.2020).

25. Бурдін В.М. Окремі питання кримінальної відповідальності за постановлення суддею (суддями) завідомо неправосудного вироку, рішення, ухвали або постанови. Актуальні питання кримінального права, кримінального процесу та криміналістики : зб. матеріалів Міжнар. наук.- 
практ. конф. (Львів, 29 січ. 2016 р.). Львів : Вид-во Львів. політехніки, 2016. C. $11-12$.

26. Проєкт Закону про внесення змін до Кримінального кодексу України щодо відповідальності за постановлення суддею (суддями) упередженого судового рішення. / Офіційний вебпортал Верховної Ради України. URL: http://w1.c1.rada.gov.ua/pls/zweb2/webproc4_1?pf3511=68868 (дата звернення: 22.05.2020).

27. Рішення Європейського суду з прав людини від 10 грудня 2009 року у справі «Мироненко і Мартенко проти України» (заява № 4785/2). / Офіційний вебпортал Верховної Ради України. URL: https://zakon.rada.gov.ua/laws/ show/974_567 (дата звернення: 25.03.2020).

28. Бангалорські принципи поведінки суддів, схвалені резолюцією 2006/23 Економічної та Соціальної Ради ООН від 27 липня 2006 року. Міжнародні стандарти незалежності суддів : збірка документів. Київ : Поліграф-Експрес, 2008. 184 с.

\section{Information about the authors:} Shcherbak I. A.,

Candidate of Law Studies (PhD), Associate Professor, Associate Professor at the Department of Constitutional, International and Criminal Law Vasyl' Stus Donetsk National University 21, 600-richya str., Vinnytsia, 21021, Ukraine

Patiuк S. O.,

Candidate of Law Studies (PhD), Associate Professor at the Department of Constitutional, International and Criminal Law Vasyl' Stus Donetsk National University 21, 600-richya str., Vinnytsia, 21021, Ukraine 